J. Dairy Sci. 104:7342-7342

https://doi.org/10.3168/jds.2021-104-6-7342

(c) 2021 American Dairy Science Association ${ }^{\circledR}$. Published by Elsevier Inc. and Fass Inc. All rights reserved.

\title{
Corrigendum to "Immunization with a novel recombinant protein (YidR) reduced the risk of clinical mastitis caused by Klebsiella spp. and decreased milk losses and culling risk after Escherichia coli infections" (J. Dairy Sci. 104:4787-4802)
}

\author{
T. Tomazi, A. C. C. H. Tomazi, J. C. C. Silva, L. Bringhenti, M. L. M. C. Bravo, M. X. Rodrigues, \\ and R. C. Bicalho
}

The ethics statement on page 4788 should read as follows (corrected text shown in bold): "This study was carried out in strict accordance with the recommendations of The Animal Welfare Act of 1985 (P.L. 99-198). The research protocol was reviewed and approved by the Institutional Animal Care and Use Committee of Cornell University (protocol number 2015-0085)."

The authors regret the error.

\section{REFERENCES}

Tomazi, T., A. C. C. H. Tomazi, J. C. C. Silva, L. Bringhenti, M. L. M. C. Bravo, M. X. Rodrigues, and R. C. Bicalho. 2021. Immunization with a novel recombinant protein (YidR) reduced the risk of clinical mastitis caused by Klebsiella spp. and decreased milk losses and culling risk after Escherichia coli infections. J. Dairy Sci. 104(4):4787-4802. https://doi.org/10.3168/jds.2020-19173. 